\title{
A Proposal to Enhance Preservice Teacher's Noticing
}

\author{
Walter F Castro ${ }^{1 *}$, Luis Pino-Fan ${ }^{2}$, Hilduara Velásquez-Echavarría ${ }^{1}$ \\ ${ }^{1}$ Universidad de Antioquia, COLOMBIA \\ 2 Universidad de Los Lagos, CHILE
}

Received 29 December 2017 • Revised 26 February 2018 • Accepted 2 April 2018

\begin{abstract}
This paper presents a proposal for the development of 'Teacher noticing' with the help of dimensions taken from the teacher's didactic-mathematical knowledge model, that makes up a Guide for Didactical Reflection. The proposal is based on a study conducted during a time span of two years while the preservice teachers were in their teaching practicum. The methodology was qualitative and data were taken in video, audio, observing rubrics, and interviews formats. The results not only indicate that the Guide can help develop teachers' noticing, in order to identify and to question several specific domains of teacher knowledge involved in mathematics teaching, but also suggest that prospective teachers are moved into action and translate their noticing in didactic action during class. We hypothesize that preservice effective noticing occurs at the intersection of practice and discussion over the practice, with the help of 'noticing tools' with respect to the mathematical activities of students.
\end{abstract}

Keywords: teacher noticing, didactic-mathematical knowledge, didactical analysis, professional development, teacher training

\section{INTRODUCTION}

Education programs for preservice teachers offer opportunities for preservice teachers to think as teachers. Teacher trainers acknowledge the need to direct the reflections of preservice teachers toward different features of the complex practice of mathematics education. Despite trainers' efforts, the preservice teachers' education is not ideal to face the challenges of mathematics teaching (Greene \& Campbell, 1993; Veenman, 1984). Teachers fresh out of the university have difficulties to respond the demands of school environment (Hebert \& Worthy, 2001).

However, the researchers have not reached an agreement as to the limits of the concept of 'teacher noticing'. Miller, Glover, Averis (2008) define the teacher noticing as the "ability to identify quickly and understand the elements of meaning in an environment" (p. 84); while Jacobs, Franke, Carpenter, Levi, \& Battey (2007) point out that it concerns the answer that the teacher gives to what he or she perceives. Other researchers try to acknowledge either the kinds of features that teachers notice (Van Es \& Sherin, 2008) or the ways to influence what teachers perceive (Miller et al., 2008; Santagata, Zannoni, \& Stigler, 2007). Certainly, the question how teachers make sense of and react to the instructional settings (Santagata et al., 2007; Star \& Strickland, 2007) is still valid.

Several research papers claim that in-service teachers change their lesson plans in function of the students' reasoning (Campbell \& White, 1997; Carpenter, Fennema, Peterson, Chiang, \& Loef, 1989; Franke, Carpenter, Levi, \& Fennema, 2001; Kazemi \& Franke, 2004 Lubinski \& Jaberg, 1997; Steinberg, Empson, \& Carpenter, 2004; Vacc \& Bright, 1999). This phenomenon is called contingency (Rowland, Huckstep, \& Thwaites, 2005). The didacticmathematical knowledge model (Pino-Fan, Assis \& Castro, 2015) propose dimensions, and sub-dimensions, where the knowledge of the mathematics teachers is organized to help them identifying and developing key skills to carry contingency processes. Star, Lynch, and Perova (2011), report that teachers have trouble identifying relevant features, both in the didactic-mathematical tasks and in the mathematical content.

The DMK model (Pino-Fan \& Godino, 2015; Pino-Fan, et al., 2015), proposes several dimensions to characterize the mathematics teacher' knowledge. Particularly, the theoretical-methodological proposal of the didactical-

(C) 2018 by the authors; licensee Modestum Ltd., UK. This article is an open access article distributed under the terms and conditions of the Creative Commons Attribution License (http://creativecommons.org/licenses/by/4.0/). \wfcastro82@gmail.com walter.castro@udea.edu.co (*Correspondence) $\square$ luis.pino@ulagos.cl 


\section{Contribution of this paper to the literature}

- The proposal to enhance teachers noticing aims to develop noticing competencies with the help of six facets for the Didactical Dimension, considered by the Didactic-Mathematical Knowledge model (DMK).

- The framework proposed by the Didactic-Mathematical Knowledge model (DMK), and the facets favor productive noticing during lesson planning, delivery and ensuing review.

- It is considered that the use of the Guide for Didactical Reflection during both teacher education and teaching practicum could be an appropriate methodological tool to promote and to support teachers' reflection on their own practice.

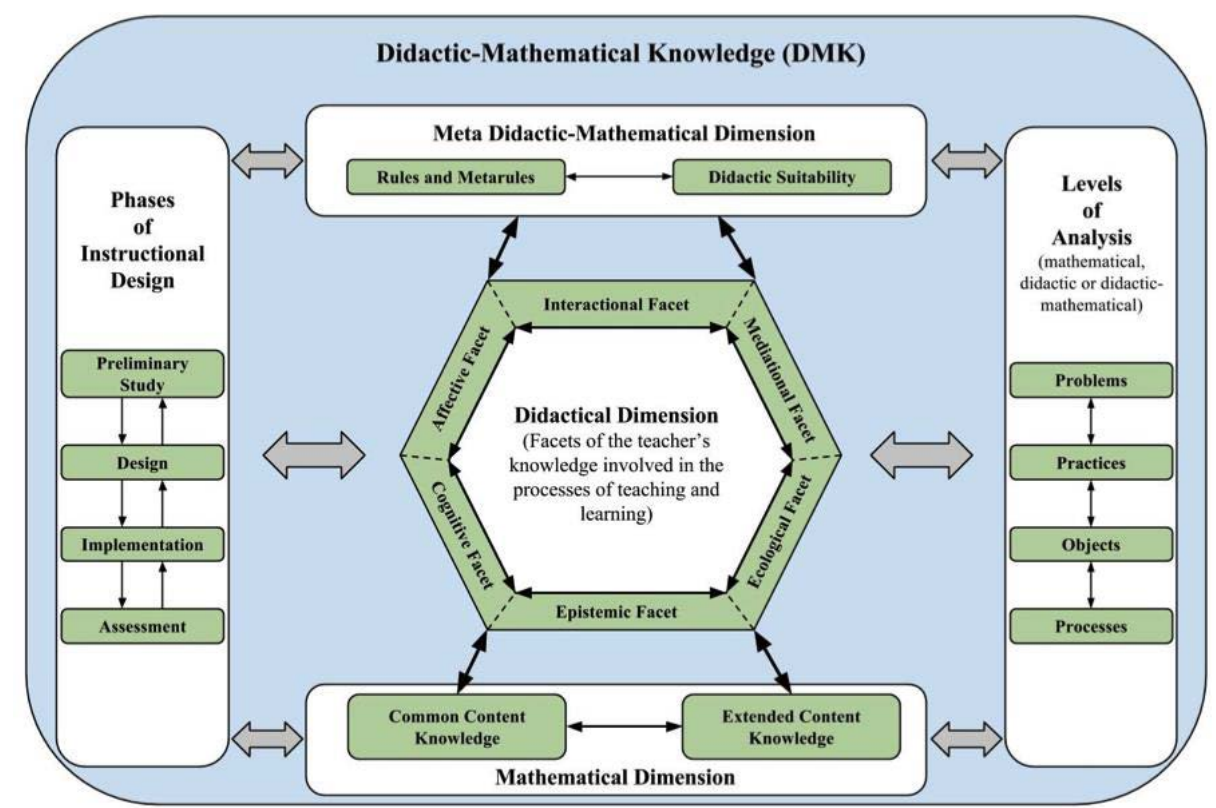

Figure 1. The DMK model (Pino-Fan, et al., 2015, p. 1433)

mathematical knowledge model (DMK), from its "metadidactical-mathematical" dimension (Breda, Pino-Fan \& Font, 2017), provides tools that allow both the reflection of the practicing teacher and the perceptions that teachers have about major features involved in both, teaching and learning mathematics objects and processes. What we propose here can help guide 'noticing' of preservice teachers, so, the aim of this paper if to report the results obtained when preservice teachers use some tools of didactical analysis proposed by the DMK model.

Some envisioned implications and applications of the study refer to their use in both, preservice teachers' training and in-service teachers' professional development. The complexity of teaching requires that not only models of teacher knowledge are proposed but also tested in the classroom to both, study their adequacy and to help teachers learn to notice the various features implied in teaching mathematics.

\section{THEORETICAL FRAMEWORK}

We have chosen the didactic-mathematical knowledge (DMK) model (Pino-Fan, Assis, \& Castro, 2015; PinoFan, Godino \& Font, 2016; Pino-Fan, Font \& Breda, 2017), to conduct this research. The DMK model is based in the Onto-Semiotic Approach to Research in Mathematics Education (OSA) (Godino, Batanero \& Font, 2007).

The DMK model (Figure 1) proposes three large dimensions for interpreting and characterizing the teachers' knowledge (Pino-Fan et al., 2016). The first dimension, mathematics, refers to the school mathematics knowledge that teachers must possess; the second refers to the knowledge of a number of features involved in teaching and learning mathematics-a deep mathematics knowledge, its interactions with students' cognition and emotions, resources, interactions in the classroom, and school context-. The meta didactic-mathematical refers to the knowledge that promotes organizing and reflecting over teachers' own practice, in order to assess the teachingand-learning practices (Breda, Pino-Fan, \& Font, 2017; Pino-Fan, Godino, \& Font, 2016).

Each of these dimensions considers subcategories of knowledge, which, also include theoretical and methodological tools that allow operationalizing knowledge analysis regarding each subcategory. Furthermore, 
these dimensions, with their corresponding analysis tools, are involved in each of the phases proposed for the elaboration of Instructional Designs: preliminary study, design, implementation and evaluation.

In a professional development program that specifically examined student work, teachers developed a deeper understanding of their students' mathematical thinking and began to develop possible instructional trajectories for their students (Kazemi \& Franke, 2004). Lubinski and Jaberg (1997) reported changes in teachers' beliefs, and those changes were reflected in their instructional practices. "The focus of the intervention was on developing students' understanding of mathematics by using teachers' knowledge of students' thinking processes" (Lubinski \& Jaberg, 1997, p. 223).

Even though these two competences are mentioned separately, their development aims to have a didactical analysis (epistemic and cognitive) where the mathematical knowledge for teaching (MKT) is carried out, as it involves: (a) a solution for the mathematical problem; which requires the development of the common knowledge of the content, (b) identification of concepts, properties and procedures involved in the process of problem solution, this identification must be done so the solution is applied and discussed with the kids; this promotes the development of the specialized knowledge of the content, (c) besides, that identification involves pointing out possible conflicts of meaning that could come up in the didactical interaction aiming to increase the adequacy of the planned teaching and learning process; this action is related to the development of the knowledge of the content and the students (Hill, Ball, \& Schilling, 2008).

In this regard a number of papers oriented to, both, the refining and the application of the DMK, have made evident that such teacher knowledge' model can be used to characterize and to develop key competencies for the teacher, such as analysis and didactic design (Pino-Fan, Font \& Breda, 2017; Breda, Pino-Fan, \& Font, 2017).

Based on the DMK didactical dimension and its different features, a Guide for Didactical Reflection was designed. It consists on a chart where the different evaluating criteria of each of the dimensions and features of the DMK model are considered. Though this chart may look static and normative (Breda, Font \& Pino-Fan, in press), it promotes the explication of the way preservice teachers read the features of the didactical component of the DMK model. Besides, it shows the features and the relations among them. This chart can be complemented in many ways and has the potential of revealing the different features of the didactical dimension in accordance with the sort of activity at hand: class topics, work guides or class episodes.

\section{METHODOLOGY AND CONTEXT}

This research was conducted during two years, from 2012 through 2014. The preservice teachers do their internship during four terms and write a report about it in the fourth term. The preservice teachers average age is 21, enrolled in their senior year in college; all of them without previous teaching experience. Due to the institution' rules, the preservice teachers taught children in third, fourth and fifth grades and they prepared both class topics and guides. The groups were assigned to the preservice teachers by the principal. The school is public, urban and enrolled only girls. The institution was chosen for two reasons: the first is that the principal is 'friendly' toward preservice teacher training conducted in his school, and the second is that we wanted to test the Guide in an institution that reported low results in standardized tests conducted locally.

The preservice teachers taught only the lessons previously agreed with the cooperating teacher. All the preservice teachers take part in discussions with their internship advisor after classes. The data discussed are taken from the recorded classes of six preservice teachers and we did not make any distinction among them.

In order to study and promote the teacher noticing during their first year of internship, we decided to use some features of the DMK model. Initially, the analysis level and the phases of instructional design were discussed with teachers and they designed both the class topics and the work guides for students, taking into account topics related to the school curriculum for elementary in accordance with the school curriculum schedule.

It should be noted that the term "class topics", in this paper, refers to a topic listed in the mathematics curriculum proposed to the preservice teachers by the cooperating teacher ${ }^{1}$, this topic must be prepared so the preservice teachers present it to the class. "Work guides" refers to materials given to kids for them to work either in group or individually. These guides are usually related to the "class topics". The episodes are moments of the class that were considered remarkable because of the features that will be presented further on. The episodes chosen offer relevant information on the interaction, between preservice teachers and students, that reveal the indicators identified for each suitability registered in the tables.

The preservice teachers taught some lessons and proposed some class guides, without knowing the Guide for Didactical Reflection and with no intervention of the internship advisor. Later on, there was a debate with all the

\footnotetext{
${ }^{1} \mathrm{He}$ is the teacher in charge of the course and the one who usually assigns tasks to the preservice teacher and assess the class once the preservice teacher has taught it.
} 
1. My mom wants to buy a piece of fabric that costs 24,80 francs $^{2}$ per meter, she needs 3,50 meters of fabric to make a

tailored suit. How much must she pay?

2. I paid 12 francs for 3 wine bottles. How much is one bottle?

3. Pedro has 12 francs and wants to buy some candy bags which cost 4 francs each. How many packs can he buy?

Figure 2. The first suggested topic

Table 1. Analysis of the indicators of didactical dimension for the topic $\mathrm{N}^{\circ} 1$

\begin{tabular}{|c|c|}
\hline Features & Indicators \\
\hline Epistemic & $\begin{array}{l}\text { 1. The situations promote representation: verbal, graphical, symbolic. } \\
\text { 2. The operation with decimal numbers corresponds to the curriculum of the grade. } \\
\text { 3. The language used is in accordance with both, the context and reality of the girls. } \\
\text { 4. The formulations and procedures required to solve the problems are key for the topic. }\end{array}$ \\
\hline Cognitive & $\begin{array}{l}\text { 1. The girls have the necessary knowledge to address the solution of the problems. } \\
\text { 2. More situations are suggested to support the process in case of difficulties expressed by the girls. }\end{array}$ \\
\hline Mediational & $\begin{array}{l}\text { 1. There are proposals to use manipulative or virtual materials to solve situations. } \\
\text { 2. The use of resources from the context to address the issue. }\end{array}$ \\
\hline Ecological & $\begin{array}{l}\text { 1. The suggested teaching situations make part of the girls' socio-cultural context. The situations are } \\
\text { meaningful and appealing. } \\
\text { 2. The contents to be developed are included in the institution' curriculum. } \\
\text { 3. The concepts, procedures and situations suggested do allow exploration of intra and interdisciplinary } \\
\text { connections. }\end{array}$ \\
\hline Affective & $\begin{array}{l}\text { 1. Solving the suggested problems is meaningful or encouraging for the girls. } \\
\text { 2. The suggested situations are within girls' everyday life, the situations do promote girls' participation. }\end{array}$ \\
\hline
\end{tabular}

preservice teachers about the Guide for Didactical Reflection applied, by the internship advisor, for two of their lessons and preservice teachers were proposed to plan the following lessons using the Guide. The discussions on the class topics, the guides and, audios and videos took place after the teachers taught the lessons. From here on, we discuss three class topics; three guides and two class episodes. Even though the didactical dimension is a "collection" of features, the ones analyzed are those that can be observed during the different moments of the internship.

\section{DATA AND ANALYSIS}

In this research we did not analyze neither the interactional aspect (Pino-Fan et al., 2015), nor its indicators while they are not easy to define.

In what follows we will present some class topics that the cooperating teacher suggested to the preservice teachers. One of the suggestions refers to: How to reinforce the concept of division.

Topic for $4^{\text {th }}$ grade: the preservice teacher suggests both three exercises and the objective of "Reinforcing the concept of division through exercises and didactical methods that favor the comprehension of the algorithm" (Figure 2).

The statements are taken from old texts (Vergnaud, 1983), they do not take into account the social or cultural reality the children live in; and "francs" was the former France currency, in any case, it does not belong the school' context.

Table 1 shows the different indicators of the Didactical Suitability suggested by Breda et al. (2017) which were suggested in the "Meta" dimension of the DMK for reflection on the practice. The indicators set conforms the Guide for Didactical Reflection that researchers discussed with the preservice teachers after each one of them taught a class to the girls. The preservice teacher introduces the topic by asking three questions presented in Figure 2.

In the first exercise the term "tailored suit" is not common to the girls due to their social context, their attention could be deviated as their interest could focus in knowing what a "tailored suit" is and not in solving the exercise. There is no need or interest in solving exercises like this, which do not belong to girls' daily life. Besides, in the fourth-grade mathematics curriculum, operations with decimal numbers are not included. The quantities 24.80 and 3.50 may be incomprehensible for the girls. The topic to be taught, proposed by the preservice teacher, does not take into account the knowledge the girls already have. Operations with decimal numbers are not known by the girls, thus, there is not any coherence between what is intended to be taught and the task proposed.

2 The underlined terms signal added emphasis. 
The second item refers to "wine bottles" which could create a conflict for the girls, given that, in their context, wine (or liquor) bottles are related to household issues which could affect the girls emotionally and, therefore, have an impact on their learning. The class claimed aim is to "favor the comprehension of the division algorithm", even though the second and third items correspond to outlines of division use, some features related to the contextualization of the curriculum are not taken into account. The Curriculum Guidelines for Mathematics in Colombia (MEN, 1998) states that the teaching situations must incorporate the affectivity and interest of the student to promote learning processes; that is, the situations are conditioned, to a greater or lesser extent, by constituent factors of every context (MEN, 1998).

The three exercises correspond to the measures multiplicative structure isomorphism (Vergnaud, 1981). The three exercises have different difficulty levels, the first one is solved through multiplication and it is operated over continuous quantities, while the second and third ones are solved through a division between discrete amounts. The second statement asks the student to find the cost per unit of a wine bottle, while the third exercise stablishes the cost of a candy pack and the quantity of packs that can be bought with twelve francs.

In the first topic proposed by the preservice teacher, the cognitive, ecological and affective features are proved to be ineffectively represented, i.e., they have a low adequacy, as the girls do not have the knowledge to solve the problem, the contents do not correspond with the curriculum, they do not acknowledge the school context and it involves situations that may not be interesting for the girls. Godino (2011) remarks that "mathematics must be taught, so they are useful for citizens and professionals, not as a closed system that does not include the applications that constitute its origin and essence" (p. 15).

The next topic-class number 2- corresponds to a class taught three weeks later.

Topic for 3rd grade class: Here is the homework that one of the preservice teachers designed to meet the cooperating teacher requirement about to "propose an activity on multiplicative structures". The preservice teacher, at the beginning of the class, introduces classroom rules to the girls. The teacher uses an activity called "break the ice" in order to get to know the girls, their names, their likes and to foster their free expression.

In the school context, mathematics classes have created stress, anxiety and rejection in students due to the severity and formalism used in the classroom; furthermore, generally the mathematics teacher is indifferent to students' emotions, teachers keep the cognitive and emotional features apart; but in teaching it is essential to consider that the student "feels" is just as important as the student "thinks"; emotions and cognition are independent and complementary mental functions; reason and emotion cannot exist independently (Bueno et al., 2005; GómezChacón, 2002). During teaching and learning teachers and students express their emotions that are essential when it intends to affect learning outcomes and the students' performance.

During the class' first part, the preservice teacher's attitude and the dialogue that he fosters allows for the exploration of likes, interests and motivation of the girls; by allowing them to express themselves he creates a tranquil learning environment and promotes a relaxed mood for the mathematics class. Later on, the preservice teacher asks: What do you do on school break? Who gets lunch money and how do you spend it? Who brings lunch from home? Who buys snacks at the school's store? On school break, do you eat alone or in group? Do you share your lunch? During this class session, the preservice teacher includes their perceptions about the girls' reality and their everyday activities; which allows for the knowledge of features of their lives, emotions and attitudes. This interaction between teacher in training and students contributes to the decrease of the feelings of anxiety, insecurity and apathy that are usually found during mathematics class. The dialogue between student and teacher during class is essential to make the students comprehend the meaning that the teacher wants to communicate (Alsina \& Domingo, 2007).

Finally, the activity "Shopping at the school store" is proposed to the girls with the purpose of identifying quantities, performing addition, subtraction, multiplications, and divisions and studying different ways to solve everyday problems. The girls are presented with the work guide (Figure 3 ) for them to solve in groups. 


\begin{tabular}{l} 
Shopping at the School Store \\
$\begin{array}{l}\text { At the school when students go out to recess, some girls gather the } \\
\text { lunch boxes and eat all together in the yard. Other girls collect all the } \\
\text { money that their parents give them and then go to buy at the school } \\
\text { store. Last Friday, } 2 \text { girls met and each put the same amount of } \\
\text { money. With the money collected they bought: } 2 \text { Small soft drinks; } 1 \\
\text { Package of spicy Detodito, and } 1 \text { Package of Boliqueso. }\end{array}$ \\
\hline $\begin{array}{l}\text { Question 1: How much money in total did the girls } \\
\text { combine together? }\end{array}$
\end{tabular}

Figure 3. Shopping at the school store activity

Table 2. Guide of Didactical Reflection for the topic presented in third grade

\begin{tabular}{|c|c|}
\hline Features & Indicators \\
\hline Epistemic & $\begin{array}{l}\text { 1. The activities favor the generation and negotiation of meanings, procedures and arguments. } \\
\text { 2. Participation during the development of activities is promoted. } \\
\text { 3. The context usefulness of mathematics is identified. }\end{array}$ \\
\hline Cognitive & $\begin{array}{l}\text { 1. The statements, procedures and jargon used are within the girls' reach. } \\
\text { 2. The girls have the required knowledge to reach the proposed activities' solution. }\end{array}$ \\
\hline Mediational & $\begin{array}{l}\text { 1. The planned time for the class is enough to develop the activities. } \\
\text { 2. The teamwork favors the dialogue and confrontation of ideas when developing activities. } \\
\text { 3. The use of resources and situations of the girls' everyday life allows assigning meanings to mathematical } \\
\text { objects. } \\
\text { 4. During the class girls are involved, and they focus and take part on the development of the proposed } \\
\text { activities. } \\
\text { 5. The presented concepts, procedures and situations are focused on key concepts of basic mathematical } \\
\text { operations. }\end{array}$ \\
\hline Ecological & $\begin{array}{l}\text { 1. The proposed class situations make part of the girls' sociocultural context and are meaningful and } \\
\text { appealing. } \\
\text { 2. Mathematical operations involved in the activity are included in the school' curriculum for 3rd grade. } \\
\text { 3. The concepts, procedures and situation allow for the exploration of interdisciplinary conexions. }\end{array}$ \\
\hline Affective & $\begin{array}{l}\text { 1. Including everyday situations promotes interest and motivation in class. } \\
\text { 2. The initial dialogue in class, promotes girls' participation, boosts confidence and eases the learning process. } \\
\text { 3. The preservice teacher's attitude and the dialogue, allows knowing the girls, their reality and creates a good } \\
\text { environment, favorable for learning, which avoids rejection or fear commonly related to mathematics. }\end{array}$ \\
\hline
\end{tabular}

Table 3. Comparison of GDR for the first two initial classes

\begin{tabular}{cccc}
\hline & Table 1 & & \multicolumn{2}{c}{ Table 2 } \\
\hline Features & Numeration & Features & Numeration \\
\hline Epistemic & $1-\underline{2}-3-4$ & Epistemic & $\underline{1-2}$ \\
\hline Cognitive & $1-2$ & Cognitive & $\underline{1-2}$ \\
\hline Mediational & $1-\underline{2}$ & Mediational & $1-2-\underline{3}-4-5$ \\
\hline Ecological & $1-2-\underline{3}$ & Ecological & $1-2-\underline{3}$ \\
\hline Affective & $1-2$ & Affective & $1-2-3$ \\
\hline
\end{tabular}

The activity "Shopping at the school store" presents questions that promote the use of multiplicative structures, "through situations and problems intended to be solved, it is like a concept that makes sense for the child" (Vergnaud, 1990, p. 133). Núñez (1996) highlights the importance of the context to learn mathematics, and promotes the use of everyday problems as a motivation to introduce new mathematical contents. This sort of task where the girls recognize the applications of mathematical operation seems to stimulate interest to solve them; the girls developed a very lively activity while solving the task.

Table 3 compares the Guides for Didactical Reflection corresponding to two initial classes analyzed with the use of Guide for Didactical Reflection (GDR), which occurred four weeks apart.

Table 3 compares the relation between the indicators of the corresponding features. We use underline, italics or bold to highlight the related features. It is important to remember that Table 1 was built by the researchers and 
Table 4. Trial records

\begin{tabular}{|c|c|c|}
\hline lest & Quantity of water & Quantity of sugar \\
\hline Test 1 & & \\
\hline Test 2 & & \\
\hline Test 3 & & \\
\hline Test 4 & & \\
\hline
\end{tabular}

discussed with the students, while Table 2 was built by the preservice teacher along with their colleagues, who attended the class session. We can observe that the students considered all the features for Table 2, and some indicators show an improvement.

Topic for 5 th grade class. Now we present the homework that one of the preservice teachers proposed when asked, by the cooperative teacher, to "propose an activity to study direct proportionality". The preservice teacher presents the following statement:

How to prepare sweetened water with the same flavor that the one made by the teacher but in a smaller container?

The preservice teacher plans to teach the class in three stages, during the first one, the activity will be explained, giving the information on how many glasses of water and sugar cubes were used. The activity is conducted in groups and each group will be given a different plastic bottle, sugar cubes and cups of 16, 4, 2 and $1 \mathrm{oz}$. which will be used to measure the quantity of water to be used in the mix. A record chart is proposed.

During the second stage of the class, a presentation of the results that each group obtained is proposed. The preservice teacher claims that he wishes to know if the girls were able, both, to differentiate the magnitudes in the homework, and to manipulated the quantities.

During the last stage of the class another question is posed to the girls; they will no longer manipulate water and sugar, but they solve the problem based on their experience.

If you need two 16 ounces cups of water and 12 sugar cubes to make sweetened water for 5 people, how many 4 ounces cups of water and cubes of sugar do you need to make sweetened water of the same flavor for 8 people?

The record chart, for the trials, allows the girls to explore, infer and proposed conjectures out from experimentation. "The operationalization of a concept must be experimented through various situations" (Vergnaud, 1990, p.139), in this case the concept of proportionality. Through the discussion of the obtained data, the girls are expected to identify the magnitudes and their variation during the trials.

The task they must complete involves the use of proportionality and it is expected that the proposed experimental dynamic favors the concept understanding. Table 5 shows the Guide for Didactical Reflection proposed by the preservice teachers. 
Table 5. Guide of Didactical Reflection for the topic of proportionality

\begin{tabular}{|c|c|}
\hline Features & Indicators \\
\hline Epistemic & $\begin{array}{l}\text { 1. The situation favors the generation and negotiation of concepts, procedures and arguments. } \\
\text { 2. It promotes different representation outlines: verbal, graphical, symbolical. } \\
\text { 3. Proposed concepts, procedures and situations are in accordance with the girls' cognitive development. } \\
\text { 4. Explanation and experimentation are in accordance with the level of education of the girls. }\end{array}$ \\
\hline Cognitive & $\begin{array}{l}\text { 1. The contents are within girls' reach. } \\
\text { 2. The language and solving processes make situational understanding easier. } \\
\text { 3. Activities allow all the girls to get involved in the solution. }\end{array}$ \\
\hline Mediational & $\begin{array}{l}\text { 1. Proposed resources are appropriate to address the topic. } \\
\text { 2. Teamwork is used as a collaborative and constructional work strategy for team discussion. } \\
\text { 3. Resources are used to address the issue. }\end{array}$ \\
\hline Ecological & $\begin{array}{l}\text { 1. Both experimentation and the proposed situation make part of the sociocultural context of the girls; they find } \\
\text { it meaningful and interesting to solve the situation. } \\
\text { 2. The contents addressed by the situation are included in the school curriculum for 5th grade. } \\
\text { 3. The concepts, procedures and proposed situation allow for the exploration of interdisciplinary connections. }\end{array}$ \\
\hline Affective & $\begin{array}{l}\text { 1. Experimentation and the proposed situation motivate girls and involve them in the situation. } \\
\text { 2. The class activity allows appreciating mathematics usefulness in girls' everyday life. } \\
\text { 3. The girls' participation, persistence, confidence and responsibility are promoted by the learning activities. } \\
\text { 4. Activities counteract the apathy and indifference toward mathematics learning, avoid rejection or fear toward } \\
\text { mathematics. }\end{array}$ \\
\hline
\end{tabular}

Table 6. Comparison of the Didactical Reflection Guides for three topics

\begin{tabular}{|c|c|c|c|c|c|}
\hline \multicolumn{2}{|c|}{$\begin{array}{l}\text { Table } 1 \\
\text { Class } 1 \\
\end{array}$} & \multicolumn{2}{|c|}{$\begin{array}{l}\text { Table } 2 \\
\text { Class } 2 \\
\end{array}$} & \multicolumn{2}{|c|}{$\begin{array}{l}\text { Table } 5 \\
\text { Class } 3 \\
\end{array}$} \\
\hline Features & Numeration & Suitabilities & Numeration & Features & Numeration \\
\hline Epistemic & $1-2-3-4$ & Epistemic & $1-2$ & Epistemic & $1-2-3$ \\
\hline Cognitive & $1-2$ & Cognitive & $1-2$ & Cognitive & $1-2-3$ \\
\hline Mediational & $1-\underline{\underline{2}}$ & Mediational & $1-2-\underline{3}-4-5$ & Mediational & $1-2-3$ \\
\hline Ecological & $1-2-\underline{3}$ & Ecological & $1-2-\underline{3}$ & Ecological & $1-2-3$ \\
\hline Affective & $1-2$ & Affective & $7-2-3$ & Affective & $1-2-3-4$ \\
\hline
\end{tabular}

A comparison between the GDR for the first topic and that for the latter two shows the indicators what preservice teachers report as the features on their most recent lesson plans. These are on the horizon of consideration that preservice teachers make during their planning and their classes.

Table 6 compares the Guides for Didactical Reflection corresponding to the three classes, which occurred along four weeks.

The activity presented in Figure 4, Cross and Circle, is developed with a pair of modified dice with the following values on their sides: $2,4,6,8,10$ and 12; so, the maximum possible value is 24 points and one of the instructions is "if a student throws the dice and gets 40 or 62 points, how many boxes does he or she moves forward?" this statement is not appropriate as it does not correspond to any of the problem conditions and could make the activity harder and become a learning obstacle. 


\section{The game of the Dice}

What characteristics do the numbers on the dice have?

What is the lowest score you can get with the dice?

What is the highest score you can get with the dice?

If a student advanced 12 squares, how many points did he get?

How many squares can he advance if he got 4 points with the dice?

How many times does 2 fit in 4 ?

How many squares can he advance if he got 6 points with the dice?

How many times does 2 fit in 6 ?

How many squares can he advance if he got 8 points with the dice?

How many times does 2 fit in 8 ?

If a student advanced 2 squares, how many points did he get?

If a student advanced 6 squares, how many points did he get?

If a student rolls the dice and gets 20 points, how many squares does he advance?

If a student rolls the dice and gets 62 points, how many squares does he advance?

Figure 4. Work guide 1 for third grade

\begin{tabular}{|llll|}
\hline \multicolumn{2}{|c|}{ Situation 1} & \multicolumn{2}{c|}{ Situation 2 } \\
\hline Box & Points & Box & Points \\
1 & 2 & 1 & \\
$x$ & 6 & 6
\end{tabular}

Figure 5. Guide for third grade

The proposed activities constitute a sort of questionnaire with repetitive questions with only one answer that do not promote discussion. The design and presentation of the activity does not have any pictures, which would be suitable for third graders.

According to the theory of conceptual fields (Vergnaud, 1990), constructing a concept is promoted through an assorted group of situations that give sense to the concept, in this case: division; however, the proposed situations are repetitive and unappealing to the girls. The situations correspond to the structure of isomorphism of measure, where three elements are known and there is the fourth one to be found. Two situations can be distinguished (Figure 5).

Situation 1. "If a student throws the dice and gets 20 points, how many boxes does he or she moves forward?"

Situation 2. "If a student moves forward six boxes, how many point did he or she get?"

Situation 1 is solved through a division between the quantity of points obtained and the value of each box, while Situation 2 is solved through a multiplication between the number of boxes and the points obtained per each box, in Figure 5.

The question: "What are the features of the numbers on the dice?" is ambiguous and does not have a defined purpose; the girls could answer about the physical features of the dice with no reference to mathematical issues. Questions like these show that the preservice teachers do not understand the cognitive aspect of the mathematics objects $^{3}$ that are intended to be discussed. The question is ambiguous as there are several valid answers; furthermore, the term "features" may not be clear for the girls. This multiplicity of options is not intentional and instead of calling for the girls' participation, makes it harder.

Table 7 presents an analysis of some indicators identified for the Learning Guide.

${ }^{3}$ Mathematics objects refer to: languages, problems, properties, concepts, procedures and arguments included in the mathematical practice (Godino, et al., 2007). 
Table 7. Guide for Didactical Reflection for the Working Guide 1

\begin{tabular}{|c|c|}
\hline Features & Indicators \\
\hline Epistemic & $\begin{array}{l}\text { 1. The statements promote different representation outlines: verbal, graphical, symbolical. } \\
\text { 2. Discussion and negotiation of concepts, procedures and arguments are proposed. }\end{array}$ \\
\hline Cognitive & $\begin{array}{l}\text { 1. The girls have the required knowledge to address the solution of the statements on the working guide. } \\
\text { 2. The contents included on the guide are in the zone of proximal development. } \\
\text { 3. The ambiguity of some statements may create cognitive conflicts to the girls. }\end{array}$ \\
\hline Mediational & $\begin{array}{l}\text { 1. Resources from the context are used to design the guide. } \\
\text { 2. Proposed situations promote discussion, argumentation or negotiation of meanings; exact answers are } \\
\text { asked for. } \\
\text { 3. Statements and the algorithm use are repetitive, which may discourage the girls. }\end{array}$ \\
\hline Ecological & $\begin{array}{l}\text { 1. Proposed contents on the guide are included in the school curriculum for } 3^{\text {rd }} \text { grade. } \\
\text { 2. Playing with dice is an activity that may foster interest in girls, but this is not the case with the proposed } \\
\text { situations. } \\
\text { 3. Proposed concepts, procedures and situations allow the exploration of intra and interdisciplinary } \\
\text { connections. }\end{array}$ \\
\hline Affective & $\begin{array}{l}\text { 1. Statements consider the everyday life of the girls, solving them is not a need; they do not promote the } \\
\text { learning of mathematics. } \\
\text { 2. Statements do not allow valuing the usefulness of mathematics in girls' everyday life. }\end{array}$ \\
\hline
\end{tabular}

Names:

1. Distribute equally and complete.

A. You have to distribute all the cookies into the four plates.

B.

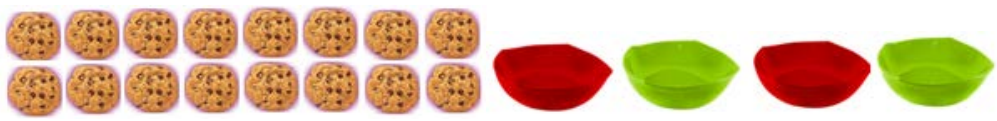

How many cookies are there on each plate? 16 divided into 4 .

B. There are 12 apples to be distributed among 3 children.

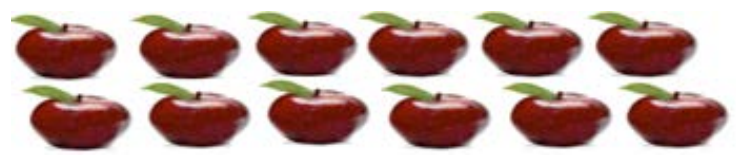

How many cookies does each child receive? 12 divided into 3

C. There are 24 bones to be distributed among 8 dogs.

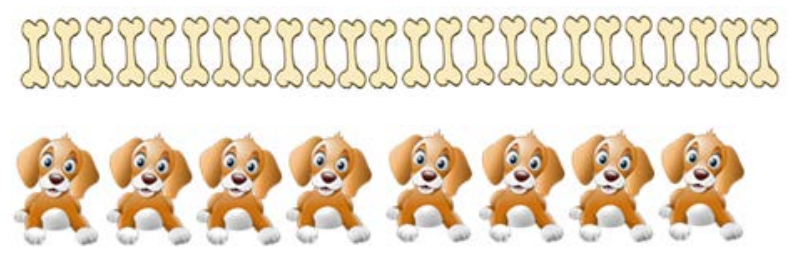

How many bones does each dog receive? 24 divided into 8 .

Figure 6. Guide for third grade

The Working Guide 2 presents guide for $3^{\text {rd }}$ grade (Figure 6).

The second guide, even though the situations are still repetitive, offers a good distribution and presentation of the activities, natural numbers division is addressed through the use of graphics, that is well accepted by the girls.

However, the proposed situations correspond to the same structure and are solved through a single process divide the quantity of objects in equal parts-, which can limit the meaning of the operation; graphical representation is favored, which is consistent with the girls' age and their cognitive development.

Table 8 presents the Guide for Didactical Reflection. 
Table 8. Didactical Reflection Guide for Working Guide 2

\begin{tabular}{ll}
\hline Features & Indicators \\
\hline \multirow{2}{*}{ Epistemic } & $\begin{array}{l}\text { 1. Different representation outlines: verbal, graphical, symbolical. } \\
\text { 2. Statements do not favor generation and negotiation of concepts, procedures and arguments. } \\
\text { 3. Situations are repetitive and are the result of the same operative process. }\end{array}$ \\
\hline Cognitive & 1. Language and contents are in accordance with the girls' cognitive level. \\
\hline Mediational & $\begin{array}{l}\text { 1. Situations in the guide foster to discuss and to confront solutions. } \\
\text { 2. Used resources and guide's layout promote girls to take part in the situations' solution. }\end{array}$ \\
\hline \multirow{2}{*}{ Ecological } & $\begin{array}{l}\text { 1. The contents of the guide are included in the school curriculum for } 3^{\text {rd }} \text { grade. } \\
\text { 2.Proposed concepts, procedures and situation allow exploring intra and interdisciplinary connections. } \\
\text { 3. Proposed situations are repetitive, they do not make part of the girls' everyday life. }\end{array}$ \\
\hline Affective & $\begin{array}{l}\text { 1. Ways to present the situations fosters girls' motivation to solve them. } \\
\text { 2.Pictures on the guide are appropriate for the girls. Pictures makes girls feel at ease when solving the situations. }\end{array}$ \\
\hline
\end{tabular}

Table 9. Guides comparison

\begin{tabular}{ccccc}
\hline & $\begin{array}{c}\text { Table 7 } \\
\text { Guide 1 }\end{array}$ & & \multicolumn{2}{c}{ Table 8 } \\
Guide 2 \\
\hline Features & Numeration & Features & Numeration \\
\hline Epistemic & $1-\mathbf{2}-\underline{3}$ & Epistemic & $\mathbf{1 - 2}-\underline{3}-4$ \\
\hline Cognitive & $1-\mathbf{2}$ & Cognitive & 1 \\
\hline Mediational & $1-2-3$ & Mediational & $1-2$ \\
\hline Ecological & $1-2-3$ & Ecological & $1-2-3$ \\
\hline Affective & $1-2$ & Affective & $1-2$ \\
\hline
\end{tabular}

Table 9 compares the two Guides for Didactical Reflection.

Even though an apparent sequence cannot be observed, it is clear that the preservice teachers notice elements of the complex set of criteria of the didactical dimension.

\section{ANALYSIS OF CLASS EPISODES}

Hereafter, an episode of a third-grade class will be presented. The aim of the class was to address natural numbers division; the following task is proposed: "When planning a birthday party, we must do some decorations; to make one of them we need half a sheet of construction paper, if a whole sheet is \$1,150; how much money do we need to buy the amount of construction paper we need?

N1: Teacher, it's impossible to know how much half a sheet is.

P: And why is that?

N1: I can't make divisions well.

P: But you know you would need to make a division.

N1: Yes, but I can't.

P: And by what number would you divide?

N1: by 2

P: There's a way to find out how much is half a sheet; how would you do it?

N1: Well, I think if I split it like this: the half of 1000 is 500 , the half of 100 is 50 , but the half of 50 (the girls stays quiet for a moment) ... there's no half of $50 \ldots$... so, I don't know.

P: Why do you think there's no half of 50 ?

N1: There are no coins less than 50 , so you can't.

The teacher in training, surprised by the girl's answer, keeps quiet for a moment and then replies:

P: The number does have a half, you just need to divide it by 2 , we can do it like that (The teacher applies the division algorithm and solves $1150 \div 2$ )

When solving mathematical problems like this, students usually use their everyday experience. The girls make transactions with coins, and claims that there are not any coins with lower denomination than 50. This episode shows how the context determines the mathematical actions developed by the students; so, the learning and teaching situations must correspond to the social and cultural environment where they take place. 
Table 10. Indicators for the analysis of Epistemic, Ecological, Affective and Interactional features

\begin{tabular}{ll}
\hline Features & Indicators \\
\hline \multirow{2}{*}{ Epistemic } & 1. The task favors generation and negotiation of meanings, procedures and arguments. \\
& 2. Explanations, verifications and solutions given by the preservice teacher are presented in a way that is \\
& related to the girls' reasoning and analysis. \\
\hline & 3. The situation promotes discussion and argumentation. \\
1. The proposed situation makes part of the sociocultural context of the girls; it is meaningful and fosters the \\
interest to solve it.
\end{tabular}

The girl's answer confuses the preservice teacher who then uses the division algorithm as the only way to solve the problem, and in doing so ignores the context where the girl's answer comes from.

The preservice teacher uses his mathematical knowledge to divide "fifty" in two, which is mathematically valid, however, for the girl, such a solution is impossible in the context of Colombian currency, given that the lowest possible value is 50 pesos, there are no coins of 25 pesos.

Table 8 analyzes the manifestation of some indicators of the teachers' didactical features -Epistemic, Ecological, Affective and Interactional-; the rest of features are not analyzed given that their elements cannot be identified.

Hereunder, we present a class episode that took place in fifth grade. The cooperating teacher asked one of the preservice teachers to develop a class about the greatest common divisor of two numbers through prime factorization. This topic had been addressed in previous classes and it is now introduced by revising exercises proposed in the last class.

In the following episode, the teacher's actions and expressions are analyzed during a segment of the class. P: Preservice teacher; N1, N2, N3: girls; Nt: Group of girls; M: Cooperative teacher.

P: We're going to check last class homework on the board, who of you couldn't do the homework?

N1: I didn't do it because I couldn't understand what I had to do.

P: But last class we explained how you had to do it, what happened?

N2: It happened the same to me, I didn't know and neither did my mom.

P: Oh ... ok then! Raise your hand if you couldn't do the homework... (As so many students raised their hands, the teacher shows surprise) ... so I will explain again with one exercise and then you come to the board to solve the rest.

$\mathrm{Nt}$ : Yes, yes, teacher...

The preservice teacher explains the process to factorize the numbers 75 and 210 into their prime factors and then finds the greatest common divisor between them.

P: Now, who wants to come here and solve the next exercise?

N3: Me, teacher, I got it.

The teacher cooperative notes that Marisella is distracted, interrupts the class and asks her to go to the board to solve the exercise [This seems to be a punishment for her lack of attention...]

Marisella tries to stand up but seems afraid, and stares at the preservice teacher....

P: Marisella, come over! you can do it! you've been distracted but I'm going to help you, here in the board we both learn.

The preservice teacher walks to Marisella's seat and takes her to the board.

P: Do you remember what we're going to do with these two numbers?

Marisella: We're going to split them into smaller numbers.

P: We're going to find their common divisors, it's like dividing them. 
Table 11. Guide of Didactical Reflection for the episode

\begin{tabular}{ll}
\hline Features & Indicators \\
\hline \multirow{3}{*}{ Cognitive } & 1. The girls have the knowledge to address the solution of the mathematical problem. \\
& 2. The mathematical contents, in this case the GCD of two numbers, is within the girls' reach. \\
& 3. There is coherence among what is taught, what is learnt and what is assessed. \\
\hline & 1. The attitude of the preservice teacher promotes the girls' participation, perseverance and confidence with \\
the learning activities.
\end{tabular}

Marisella: Ah, I got it, we've got 198, I can divide it in half.

$P:$ and that is dividing it by what number?

Marisella: by 2

P: and why 2?

Marisella: Because its last digit is an even number.

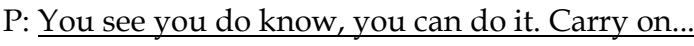

The girl keeps on doing the exercise on the board and she completes it successfully.

Table 11 lists some indicators for the didactic-cognitive, affective-emotional and interactional features proposed by the teachers.

When the girls have difficulties to solve the exercise, the preservice teacher understands and addresses their doubts, and listens to girls, which favors their participation.

When Marisella stares at the preservice teacher, she is looking for support, because she feels uneasy due to command of the cooperative teacher; here, the preservice teacher shows empathy ${ }^{4}$ and interest in the girls' predicament, takes a fraternal and respectful attitude, giving her confidence and boosting her self-esteem.

The expression "here on the board we both learn", uttered by the preservice teacher, shows empathy toward the girls; acknowledges that the learning is not the girls' task, exclusively, that the teacher also takes part in the process. When she takes the girl's hand and walks with her to board, she shows affection and tenderness, showing both respect to the girls and trust in their abilities.

Expressions such as "you can do it", "I'm going to help you", "you see, you can do it", promotes the girls' participation in the activities. Fernández, Palomero, and Teruel (2009) claims:

\section{It is essential for the teachers to know to see the students as they are, in their identity. It is fundamental for the teacher to appreciate them and trust them, as the kid can only trust himself if he sees that others trust him and appreciate what he is (p.44).}

During the Seminar sessions it was discussed that the affective feature seems absent when designing and executing the task. This episode is an evidence of the influence of the affective-emotional dimension in the teaching and learning process; the preservice teacher must also be focused on the development of personal, social and affective abilities. The indicators were discussed with the preservice teachers, and with the cooperating teacher. In order to test them, the same set of indicators were used and discussed by in-service teachers, that were teaching the same mathematic topics. Such data are not considered on this report.

\footnotetext{
${ }^{4}$ Empathy is the ability to put oneself in other person's shoes and understand what they live and feel, even when they do not express it. When people know themselves and are able to catch their feelings and what causes them, they are better enabled to perceive and understand the others (Fernández, et al., 2009, p.44)
} 


\section{CONCLUSIONS}

Final considerations for this research are presented: first, it considers the assessment of the tools of the DMK model for promoting teacher noticing; second, it takes into account the training of preservice teachers.

The six features of the didactical dimension of DMK were used both as a tool to analyze the didacticalmathematical knowledge of the six preservice teachers who participated in the research, and to highlight features of the teaching practice that could be improved. The analysis conducted on the topics, teaching guides and class episodes allowed adapting the DMK indicators for reflection on the six features of the didactical dimension. Even though the identification of the indicators takes place after the implementation of the classes, it is observed that preservice teachers not only identify indicators but they also use them as criteria to develop the class. It could be said that this backs the results of some studies (Breda et al., 2017) that inform that even though training processes are not conducted with either preservice teachers or in-service teachers, they use implicitly the suitability indicators to reflect on their practice.

It is difficult to identify indicators for the affective feature in the lesson plans and working guides, those are identifiable in the class episodes. Contrasting the indicators of the six features for the didactical dimension for each activity allows observing didactical features that are either identified or ignored by preservice teachers. The indicators offer an accurate observation tool for the tutor of the practice. It is observed that preservice teachers identify indicators since the first time they use them, and they try them for the topics in the following guides; however, identification is made not only based on the use of the Guide for Didactical Reflection but also to both debating, held in the Practice Seminar, and the dialogues on teaching and learning. The Guide for Didactical Reflection must be used along with discussion sessions both with the cooperative teacher and the practice advisor. At the beginning of the internship, the Guides and their activities had a very formal design; but as the time went by, there were some important changes on the design.

In order to analyze the preservice teachers' didactical-mathematical knowledge we decided to study it on the classroom, considering it in different strands -cognitive, epistemic, mediational, affective, interactional and ecological features-. These dimensions included the design, application and assessment of teaching and learning in the classroom, which included the verification of lesson plans, resources employed, designs activities, proposed learning tasks for students, programmed contents, communicative actions, class organization, time management, attitudes, emotions, beliefs and values, and influence of social and cultural environment on the instruction processes.

The managing of such complexity needs specific training. One of the specific objectives of teacher noticing presented on this research is 'to promote the reflection by the preservice teachers on the didactic-mathematical knowledge that they show during their teaching internship'. During classes it was noted that preservice teachers managed to take a critical and thoughtful view on their role as teachers; the institutional context along with the Guide for Didactical Reflection favored the teacher changing some of their perceptions about 'being a teacher'. They acknowledge the complexity of the teaching practice and admit that besides the disciplinary and didactical knowhow, it is necessary, for the teacher, to acknowledge other dimensions to have a more complete view on the task at hand. The reflection process promoted by the Guide for Didactical Reflection, allowed preservice teachers improving their teacher noticing competences. This is relevant finding because during the two years that the research lasted, we find evidence that the DMK favors the development of key competencies for the teachers' professional practice such as didactic analysis and didactic design that are close related to teachers noticing.

In regard to the affective and ecological features of teaching the preservice teachers, we found that the Guide for Didactical Reflection favors the identification of the importance of the indicators in the process of teaching and learning, the emotional-affective part cannot be ignored in education, on the contrary, it is the foundation of efficiency in teaching and learning. Indicators proposed in Table 1 made clear the incidence that this dimension has in the mathematical instruction processes.

The affective-emotional dimension has been forgotten in the training of teachers; the preservice teachers reflect in their action, the values, attitudes, beliefs, emotions and feelings that come from their personal and familiar background and past experiences; however, in some cases, they prevent them from acting in an assertive way. Their communicative processes, the language used, expression, gestures, emotions, motivation and empathy for their tasks and students are determining factors in mathematical teaching and learning, the efficiency of educational processes depend on them. The affective dimension has a direct relationship to the cognitive dimension. A change in any of them affects the other (Gómez-Chacón, 2002). The teacher's roll demands having skills to regulate not only his own feelings but also students' feelings (Extremera \& Fernandez, 2003). In his daily classroom work, the teacher puts at play features associated to affective dimension, such as gestures and verbal expressions, that are integral to his professional realm.

Regarding the ecological feature, we can conclude that the social, cultural and school environment affects and determines the actions taken by different education stakeholders. Teachers identified the way girls solve 
mathematical problems based on their everyday experience, rather than on their school mathematical knowledge; the teacher's training cannot be indifferent to school contexts and realities; the internship is the place where the relevance of the context in the instruction process is identified, it determines actions of both, teachers and students.

On the other hand, as a reflection on the teachers training processes, it seems important to include emotional education in the curriculum; schools of education must transcend epistemic and cognitive emphasis and complement it with training in the affective-emotional aspect, as the teachers are the ones who will contribute to the education of children and teenagers. In our society plagued with social and familiar conflicts, students need greater support from teachers.

Considering emotional features in teaching is a 'must' in teacher's education, based on such education teachers can, both, identify students' emotions and develop abilities to take a positive attitude towards teaching, learning and student's behavior, that in turn, could help them to take advantage of the opportunities school offers (Bisquerra, 2005).

Several researches have gone deeper on problems related to teaching and learning of mathematics; some of them have tried to document the importance of the affective-emotional dimension in teaching processes (Bisquerra, 1998, 2000; Fernández et al., 2009; Teruel, 2000); but education schools need to guide teachers training toward the development of socio-affective values, the enhancing of attitudes of respect, tolerance, self-esteem, the harmonic management of emotions and feelings. There a number of fine research papers on teachers noticing collected in the book edited by Schack, Fisher and Wilhelm (20017) that offer a wide perspective on the subject, but our proposal offers a tool that can be used in various school settings, grade bands and contexts, with all mathematics subjects. Nonetheless, more research is needed to test if our proposal can be used along with some theoretical frames.

One drawback of this study is that the researchers could not propose neither the tasks preservice teachers discussed in the classroom nor conduct a follow up study to find if the preservice teachers, once graduated, continue using the Guide to prepare their classes.

Another one was that some of the tasks discussed with the researchers were not implemented in the class due to institutional constraints. Among this research strengths we could point out two: the first is the use of an emergent teacher knowledge model that takes into account the complexity of teaching mathematics, and lists some features that a teacher must consider while designing and teaching. The second one is that the features allow its use through the Guide for Didactical Reflection, that helps preservice teachers to identify indicators as 'didactic variables' that will help them 'to notice', a competency that every teacher should have and develop to perform his teaching duties efficiently. According to the research results it seems that the Guide, along with a tutor, is a good instrument, for the preservice teachers, to notice that teaching is much more that presenting mathematics topics on the blackboard.

We consider that the Guide is a good 'noticing instrument', but need to be accompanied with a peer or a tutor, that helps identifying, questioning and modifying the indicators. In this respect, 'teachers noticing' is a competency to be developed and honed not in isolation.

It is necessary to train the teacher, not only on disciplinary and didactical knowledge, but also on the emotional features, which allows teacher to interact with pupils, develop an adaptation capacity, social skills, increase empathy, self-control, increase self-esteem, enthusiasm, motivation, increase assertively avoiding passiveaggressive behavior, increase perseverance, management of rejection and stress situations, increase the capacity to make decisions with confidence which will allow him to act in a more efficient, just and balanced way both personally and socially. In order to test the proposal further, a research should be conducted with in-service teachers and in a number of different school contexts to hone the instrument of teacher noticing.

\section{ACKNOWLEDGEMENTS}

This article has been developed within the framework of the research project on teacher training Fondecyt 11150014, financed by Comisión Nacional de Investigación Científica y Tecnológica (CONICYT) de Chile.

\section{REFERENCES}

Alsina, A., \& Domingo, M. (2007). Cómo aumentar la motivación para aprender matemáticas. Suma, (56), 23-31.

Bisquerra, R. (1998). Educación emocional. Barcelona: Praxis

Bisquerra, R. (2000). Educación emocional y bienestar. Barcelona: Praxis

Bisquerra, R. (2005). La educación emocional en la formación del profesorado. Revista Interuniversitaria de formación del profesorado, 19(3), $95-114$.

Breda, A., Font, V., \& Pino-Fan, L. (2018). Criterios valorativos y normativos en la Didáctica de las Matemáticas: el caso del constructo idoneidad didáctica [Evaluative and normative criteria in Didactics of Mathematics: the 
case of didactical suitability construct]. BOLEMA, 32(60), 255-278. https://doi.org/10.1590/1980$4415 \mathrm{v} 32 \mathrm{n} 60 \mathrm{a} 13$

Breda, A., Pino-Fan, L., \& Font, V. (2017). Meta didactic-mathematical knowledge of teachers: criteria for the reflection and assessment on teaching practice. Eurasia Journal of Mathematics, Science \& Technology Education, 13(6), 1893-1918. https:/ / doi.org/10.12973/eurasia.2017.01207a

Bueno, C., Teruel, M. P., \& Valero, A. (2005). La inteligencia emocional en alumnos de magisterio: La percepción y comprensión de los sentimientos y las emociones. Revista Interuniversitaria de formación del profesorado, 19(3), 169-194.

Campbell, P., \& White, D. (1997). Project IMPACT: Influencing and supporting teacher change in predominantly minority schools. In E. Fennema \& B. Nelson (Eds.), Mathematics teachers in transition (pp. 309-355). Mahwah, N.J.: Erlbaum.

Carpenter, T. P., Fennema, E., Peterson, P. L., Chiang, C. P., \& Loef, M. (1989). Using knowledge of children's mathematics thinking in classroom teaching: An experimental study. American Educational Research Journal, 26, 499-531. https://doi.org/10.3102/00028312026004499

Extremera, N. \& Fernández, P. (2003). Inteligencia emocional en el contexto educativo: Hallazgos científicos de sus efectos en el aula. Revista de educación, (332), 97-116.

Fernández, M., Palomero, J., \& Teruel, M. (2009). El desarrollo socioafectivo en la formación inicial de los profesores. Reifop, 12(1), 33-50.

Franke, M. L., Carpenter, T. P., Levi, L., \& Fennema, E. (2001). Capturing teachers' generative growth: A follow-up study of professional development in mathematics. American Educational Research Journal, 38, 653-689. https:// doi.org/10.3102/00028312038003653

Godino, J. (2011). Indicadores de la idoneidad didáctica de procesos de enseñanza y aprendizaje de las matemáticas. XIII Conferencia Interamericana de Educación Matemática. CIAEM. Recife, Brasil.

Godino, J., Batanero, C., \& Font, V., (2007). The onto-semiotic approach to research in mathematics education. ZDM. The International Journal on Mathematics Education, 39(1-2), 127-135. https://doi.org/10.1007/s11858-0060004-1

Gómez-Chacón, I. (2002). Afecto y aprendizaje matemático: causas y consecuencias de la interacción emocional. En J. Carrillo (ed.) Reflexiones sobre el pasado, presente y futuro de las Matemáticas. Huelva.

Greene, M., \& Campbell, C. (1993). Becoming a Teacher: the contribution of teacher education, ERIC Report ED369769 45, Alberta, Canada.

Hebert, E., \& Worthy, T. (2001). Does the first year of teaching have to be a bad one? A case study of success. Teaching and teacher education, 17, 897-911. https:/ / doi.org/10.1016/S0742-051X(01)00039-7

Hill, H., Ball, D., \& Schilling, S. (2008). Unpacking “pedagogical content knowledge": Conceptualizing and measuring teachers' topic-specific knowledge of students. Journal for Research in Mathematics Education, 39(4), 372-400.

Jacobs, V. R., Franke, M. L., Carpenter, T. P., Levi, L., \& Battey, D. (2007). Professional development focused on children's algebraic reasoning in elementary school. Journal for Research in Mathematics Education, 38, 258288.

Kazemi, E., \& Franke, M. L. (2004). Teacher learning in mathematics: Using student work to promote collective inquiry. Journal of Mathematics Teacher Education, 7, 203-235. https://doi.org/10.1023

Lubinski, C., \& Jaberg, P. (1997). Teacher change and mathematics K-4: Developing a theoretical perspective. In E. Fennema and B. Scott Nelson (Eds.). Mathematics teachers in transition (pp. 223-254). Mahwah, NJ. Lawrence Erlbaum Associates.

Miller, D. J., Glover, D., \& Averis, D. (2008). Enabling enhanced mathematics teaching: Final Report for the National Centre for Excellence in the Teaching of Mathematics. Retrieved on June 15, 2011 from http://www.keele.ac.uk/media/keeleuniversity/fachumsocsci/sclpppp/education/interactivewhiteboar d/ncetmreport-1.pdf

Ministerio de Educación Nacional. (1998). Lineamientos Curriculares de Matemáticas. Bogotá.

Núñez, C. (1996). Lo que subyace tras el comportamiento de nuestro alumnado en una clase de matemáticas. Revista Uno, (7), 118-124.

Pino-Fan, L., \& Godino, J. D. (2015). Perspectiva ampliada del conocimiento didáctico-matemático del profesor [An expanded view of teachers' didactic-mathematical knowlodge]. PARADIGMA, 36(1), 87-109. 
Pino-Fan, L., Assis, A., \& Castro, W. F. (2015). Towards a methodology for the characterization of teachers' didacticmathematical knowledge. Eurasia Journal of Mathematics, Science \& Technology Education, 11(6), 14291456. https:/ / doi.org/10.12973/eurasia.2015.1403a

Pino-Fan, L., Assis, A., \& Godino, J. D. (2015). Análisis del proceso de acoplamiento entre las facetas epistémica y cognitiva del conocimiento matemático en el contexto de una tarea exploratorio-investigativa sobre patrones. Educación Matemática, 27(1), 37-64.

Pino-Fan, L., Font, V., \& Breda, A. (2017). Mathematics teachers' knowledge and competences model based on the onto-semiotic approach. In B. Kaur, W. K. Ho, T. L. Toh \& B. H. Choy (Eds.), Proceedings of the 41st Conference of the International Group for the Psychology of Mathematics Education (Vol. 4, pp. 33-40). Singapure: PME.

Pino-Fan, L., Godino, J. D., \& Font, V. (2016). Assessing key epistemic features of didactic-mathematical knowledge of prospective teachers: the case of the derivative. Journal of Mathematics Teacher Education. http:/ / dx.doi.org/10.1007/s10857-016-9349-8

Rowland, T., Huckstep, P., \& Thwaites, A. (2005). Elementary teachers' mathematics subject knowledge: the knowledge quartet and the case of Naomi. Journal of Mathematics Teacher Education, 8(3), 255-281. https:/ / doi.org/10.1007/s10857-005-0853-5

Santagata, R., Zannoni, C., \& Stigler, J. (2007). The role of lesson analysis in pre-service teacher education: An empirical investigation of teacher learning from a virtual video-based field experience. Journal of Mathematics Teacher Education, 10(2), 123-140. https:/ / doi.org/10.1007/s10857-007-9029-9

Schack, E. O., Fisher, M. H., \& Wilhelm, J. (2017). Teacher noticing: Bridging and broadening perspectives, contexts, and frameworks. New York: Springer.

Star, J. R., \& Strickland, S. K. (2007). Learning to observe: using video to improve preservice mathematics teachers' ability to notice. Journal of Mathematics Teacher Education, 11(2), 107-125. https://doi.org/10.1007/s10857007-9063-7

Star, J. R., Lynch, K., \& Perova, N. (2011). Using video to improve preservice mathematics teachers' abilities to attend to classroom features. In M. G. Sherin, V. R. Jacobs \& R. A. Philipp (Eds.), Mathematics teacher noticing: Seeing through teachers' eyes (pp. 117-133). New York: Routledge.

Steinberg, R. M., Empson, S. B., \& Carpenter, T. P. (2004). Inquiry into children's mathematical thinking as a means to teacher change. Journal of Mathematics Teacher Education, 7, 237-267. https:/ / doi.org/10.1023/B:JMTE.0000033083.04005.d3

Teruel, M. P. (2000). La inteligencia emocional en el currículo de la formación inicial de profesores. Revista Interuniversitaria de formación del profesorado, (38), 141-152.

Vacc, N., \& Bright, G (1999). Elementary preservice teachers' changing beliefs and instructional use of children's mathematical thinking. Journal for Research in Mathematics Education, 30(1), 89-110.

Van Es, E. A., \& Sherin, M. G. (2008). Mathematics Teachers' "Learning to Notice” in the Context of a Video Club. Teaching and Teacher Education, 24, 244-276. https:// doi.org/10.1016/j.tate.2006.11.005

Veenman, S. (1984). Perceived problems of beginning teachers. Review of Educational Research, 54(2), 143-178. https://doi.org/10.3102/00346543054002143

Vergnaud, G. (1981). L'enfant, la mathématique et la réalité. Berne, Peter Lang.

Vergnaud, G. (1983). Multiplicative structures. Acquisitions of mathematics concepts and processes. In R. Lesh y M. Landau (Eds.), 127-174.

Vergnaud, G. (1990). La teoría de los campos conceptuales. Recherches en Didactique des Mathématiques, 10(2-3), 133170.

\section{http://www.ejmste.com}

